\title{
Assessing Multiliteracies: Mismatches and Opportunities
}

\author{
MARIA JOSÉ BOTELHO \\ University of Massachusetts Amherst \\ JULIE KEREKES, EUNICE JANG \& SHELLEY STAGG PETERSON \\ Ontario Institute for Studies in Education, University of Toronto
}

\begin{abstract}
While current literacy theories acknowledge the sociocultural and sociopolitical dimensions of literacy learning and teaching, that is, multiliteracies, there exists a gap between theoretical approaches underpinning literacy teaching and assessment. In this dialogue, we re-enact this divergence by collectively defining multiliteracies and deconstructing assessment practices, while speculating on opportunities for reconstruction. Constructing this dialogue across multiple areas of expertise exemplifies multiliteracies because we use critical speaking, listening, writing, reading, and representing, to make sense of our new understandings, and showcase our knowledge construction. Our goal is to explore ways to translate the theories of multiliteracies into assessment practices that make visible children's cognitive-psychological, psycholinguistic, sociocultural, and sociopolitical processes with all kinds of texts.
\end{abstract}

\section{Introduction}

While current literacy theories acknowledge the sociocultural and sociopolitical dimensions of literacy learning and teaching, that is, multiliteracies (Cope \& Kalantzis, 2000; Cummins, 2004; New London Group, 1996; Pahl \& Rowsell, 2005/2012; Rowsell, 2013; Street, 2005), there exists a gap between theoretical approaches underpinning literacy pedagogies and assessment practices. In the following dialogue, we situate and deconstruct current assessment tools and speculate on possibilities for their reconstruction in ways that recognize multiliteracies. Our goal is to translate the theories of multiliteracies into assessment practices that make visible children's cognitivepsychological, psycholinguistic, sociocultural, and sociopolitical processes with literacies (Hall, 2003).

These four literacy perspectives shape how literacies are defined and how children's literacies are observed, assessed, as well as sometimes overlooked. A sociopolitical perspective of literacy (Comber \& Simpson, 2001; Janks, 2010) acknowledges that texts are not neutral and represent particular worldviews and silence other perspectives, contributing to how readers perceive their place in the world. A sociocultural perspective (Dyson, 2003; Vygotsky, 1978) places culture at the center of literacy, as a set of social practices that children, families, and communities engage in on a daily basis, with a focus on meaning making, prior knowledge, and interactions with adults, peers, and tools. A psycholinguistic perspective (Goodman, 1986; Holdaway, 1979) recognizes children's predisposition to acquire language from their environment 
through exposure and to determine its rules for themselves. The mistakes that children make offer insights into rule-making processes. The psycholinguistic perspective rejects the linear processes theorized by behaviorist psychologists and recognizes children as agents of their own learning. A cognitive-psychological perspective of literacy (e.g., Chall, 1983) defines these practices as a set of cognitive skills, processes that happen in children's heads, thus rendering these practices as personal and isolated from children's sociocultural contexts. Literacy pedagogies exclusively informed by this latter perspective privilege systematic and sequenced teaching of reading, anchored by developmental stages that standardize children's learning processes.

Many of the assessment tools used in schools privilege cognitive-psychologicaland psycholinguistic-based reading and writing practices concerned with decoding text through phonological, graphic, morphological, and technical spelling skills, while neglecting their sociocultural and sociopolitical dimensions and isolating them from the other language modes (Bryant, 1994; Street, 1993). We argue that speaking, listening, writing, reading, representing, and viewing are processes that work together and inform each other. Luke and Freebody's (1999) conceptual framework of the four literacy practice model (i.e., code breaking, text participating, text using, and text critiquing), practices that we explore later on in this article, showcases the complexities of multiliteracies and the practices of experienced and critical readers, writers, speakers, listeners, and designers.

We draw on multiliteracies pedagogies and theories (Cope \& Kalantzis, 2000 \& 2013; New London Group, 1996; Rowsell, 2013) to conceptualize literacy practices as a dynamic and complex repertoire of social practices that help children participate in their everyday lives. These literacy practices are shaped by social purpose and context. Multiliteracies theories support teaching practices that:

- invite children to use their first languages, multiple dialects of English, and literacies as resources for learning;

- demonstrate that speaking, listening, writing, reading, representing, and viewing are processes;

- create learning experiences that connect these language modalities;

- help all children to access languages (e.g., standard Canadian and American English) and literacies of power (e.g., school writing practices);

- consider literacy practices as tools for children to understand themselves and actively participate in the world;

- enable children to construct knowledge and create multiple texts through dialogue and critical inquiry;

- use digital technologies and other modalities (e.g., visual representations, movement, drama, etc.) as tools to support children's construction of knowledge and make visible their meaning making;

- temper computer use with guided practice and critical conversations about digital literacies and their influence on learning and social interaction; and,

- facilitate text production through materials, media, and modes, processes and practices that contribute to children's critical literacies. (Botelho, 2007; Botelho, Cohen, Leoni, Chow, \& Sastri, 2010) 
Johnston and Costello (2005) maintain that literacy assessment always involves representation and interpretation; ever-changing social practices and discourses; impositions of particular relationships and practices of being literate; and social consequences for children and their communities, thus, constructing their place(s) in the world. Literacy assessment tools shape what gets noticed and overlooked about children's literacy practices. Assessments are representations, that is, social constructions of children's learning. Furthermore, the adults' relationships to children influence how the assessments are interpreted. For example, a principal might interpret "the results" differently than the classroom teacher or parent. The assessment tool is largely shaped by how literacy is conceptualized within school contexts and the discourses associated with literacy learning. For instance, if we tolerate certain labels associated with children's reading practices or inexperience with school reading (e.g., "struggling reader," "low level reader"), those labels will shape the assessment practice, which in turn will shape the teaching and what children learn within classroom contexts. All of these social practices and discourses have particular consequences for children. Johnston and Costello (2005) caution that we need to take stock of what we assess and how we assess. Cognitive-psychological and psycholinguistic theories of literacy primarily inform the tools available to assess school literacy practices and do not recognize children's cultural and linguistic resources (Burke \& Hammett, 2009; Gee, 2003; Jewitt, 2003; Johnston \& Costello, 2005; Johnson \& Kress, 2003; Kalantzis, Cope, \& Harvey, 2003).

This article represents a dialogue among four researchers who draw on a range of theoretical perspectives "to problematize a wider range of assumptions about assessment and to imagine a wider range of alternative practices" (Moss, Pullin, Gee, \& Haertel, 2005, p. 66). Together, we examine questions about the ideological underpinnings of literacy assessment practices. By questioning the taken-for-granted validity of cognitivepsychologically- and psycholinguistic-based tools for assessing students' learning, we deconstruct examples of current practices and create the possibility of reconstructing them to document, represent, and respond to children's multiliteracies learning as they use these literacy practices within different contexts, for different purposes and audiences (Johnston \& Rogers, 2001).

\section{Constructing a Dialogue as a Way of Understanding}

In the spring of 2006, motivated by current trends in Ontario's educational assessment policies and practices, the four of us arranged a set of meetings to explore what we knew about literacy assessment within the context of Ontario's public schools, and to use our respective expertise to extend our jointly constructed critique of current assessment practices. Not quite sure where our conversations would take us, we chose to audio-record all of our discussions. After several meetings and many hours of transcribing, we began to discern that our understandings were continually being constructed discursively - that is, through our dialogue process with each other and other researchers through our speaking, writing, and reading: We articulated, reconsidered and reformulated our positions as we also attended to our language use. We wanted to share this co-construction of ideas by reconstituting our conversations, in a negotiated and edited format, for others, thus making our process public. We transcribed our conversations and then culled excerpts and located themes that could promote a 
continued deconstruction and reconstruction of literacy assessment practices while enlisting other voices from the research literature to support our inquiry. We continued our dialogue over a five-year period as we considered and folded the feedback that we received from colleagues, conference participants, and manuscript reviewers into this hybrid text.

What follows, then, is our "dialogic play," as we have come to refer to it - words we have gathered from our mouths, some borrowed from other researchers and practitioners in our respective fields, and some responses to the anticipated engagement with our work. This dialogic play is a representation of our shared intention, our shared discourse (Bakhtin, 1986). Much in the spirit of Gordon Wells' $(2001,2007)$ dialogic inquiry and Mary Horton-Salway's (2001) discursive action model, these practices showcase the role of social interaction in knowledge production and how our discourse (language use) and critical collaboration constructs our thinking. Tineke A. Abma's (2002) work inspired us to construct this dialogic play as a representation of our resistance to the disembodied qualities of academic writing. While we attached names to each other's contributions, we lend each other our words and drew on the research literature as we represented turn taking, elaboration, and new contributions. However, we are not so much concerned with projecting our voices as we are with offering a "more textual orientation... a closer attention to what is written [and how it was written]...rather than ...who has written" (Kamler, 2001, p. 45). We use pseudonyms to remind the reader that our contributions are composites of each other's and other scholars' words. Lastly, this dialogic play has created opportunities to further critical engagement with these pedagogical issues as our students read and perform it in our graduate courses (Goldstein, 2008). It is the readers' critical reading that ultimately will embody this intertextual play.

In face-to-face dialogue we contributed, responded, and built on our shared understandings. Our transcribed words alongside the research literature on multiliteracies and assessment became the data for deconstruction and reconstruction, allowing us to "catch language in the act of [constructing] subjectivities" (Davies, 2000, p. 142) and reflect on these constructions of self and engage in respeaking, rereading, and rewriting our understandings and discursive practices. As we documented the unfolding of our conversations, we discovered the context and nexus of the assessment debate, which required further examination in order to develop this exploration. As products of this collective work, we published an article on assessing writing from a multiliteracies perspective (Peterson, Botelho, Jang, \& Kerekes, 2007) and performed this dialogue as a play, the last act of which was co-performed with members of the audience at a national conference in Canada and with international visiting scholars in our department. We now invite you, the reader, to participate in our dialogue.

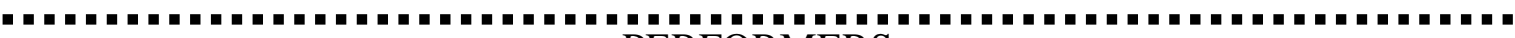
PERFORMERS

Amherst...................a researcher of critical literacies, multiliteracies, Waldorf literacy practices, and critical collaborative inquiry.

Haemi ....................a researcher of fair and valid educational and language assessment practices.

Dorina.....................a researcher of discourse, second language use and acquisition in their sociolinguistic contexts. 
Ferintosh a researcher of classroom writing and large-scale literacy assessment.

\section{SETTING}

Ferintosh, Dorina, Haemi, and Amherst are good friends and colleagues in the Department of Curriculum, Teaching and Learning at the Ontario Institute for Studies in Education of the University of Toronto. Sitting around a table in Dorina's office, a space that overlooks one of the most culturally and linguistically diverse cities in the world, they participate in a critical collaborative inquiry into the complexities of literacy assessment.

\section{Act 1}

Scene 1, early morning in Dorina's office: The Mismatch

\section{Amherst:}

When I teach my pre-service language arts course, I have my students read a text about multiliteracies pedagogies and we explore the possibilities of reconceptualizing literacy in the classroom. And then we consider different kinds of assessment tools like reading and writing surveys, observation checklists, and running records, for example, but... then I noticed a mismatch between multiliteracies pedagogies and the available literacy assessment tools. Many of the tools reduce literacy to reading and writing as cognitive-psychological and psycholinguistic practices, and, as if these literacy practices are the only two language modes available to children. Literacies' sociocultural and sociopolitical dimensions are completely overlooked.

\section{Haemi:}

I agree. What I've observed is that many new exciting social practices ${ }^{\mathrm{i}}$ are taking place in the classroom. These days, students are doing more problem solving activities that require creative thinking. They represent their work as a drama or role-play, for example, and then perform it. But then how do we assess their participation in the performance? Can we assess those literacies? Should we assess them? For example, while the Ontario Secondary School Literacy Test (See http://www.eqao.com/pdf_e/13/ OSSLT_PlanningPreparationGuide_2013.pdf.) incorporates several genres for reading (e.g., informational text, news report, graphic text) and writing (e.g., news report, persuasive writing), it still reduces literacy to the modes of reading and writing on the medium of paper and comprehension as literal meaning, distracting readers from the connections and "disconnections" (Jones, Clarke, \& Enrique, 2010) they might make in actively engaging with each text. These processes are shaped by the readers' background knowledge, culture, and context. It's as if... assessment takes place completely separate from students' learning and living. That troubles me.

\section{Dorina:}

Let's keep in mind that students are expected to write a three-paragraph-long opinion piece in the literacy test, a space for drawing on their lived experience. However, the test conditions shape what gets written. 


\section{Ferintosh:}

I've noticed that there seems to be a schism between teaching and assessment with our literacy understandings and practices moving far beyond the psychological to the sociocultural realm, whereas the assessment practices are primarily cognitivepsychological. For example, running records assess how children use the semantic, graphophonemic, and syntactic cueing systems in oral reading. Running records (see an e-worshop on running records at http://eworkshop.on.ca/edu/core.cfm?p=main\&mod Colour=1\&modID=2\&m=121\&L=1) are what Johnston (2000) calls "an estimate of the reader's mental processes" through analysis of error patterns (p. 1). Some teachers also pay close attention to how children use language pragmatically, that is, examining what the reader deems important and needs to understand during the reading. The pragmatic system is mostly ignored, reducing running records to a transcript of cognitive strategies.

\section{Amherst:}

Exactly. The cognitive-psychological perspective extracts children from their social context and renders them as individual readers and writers engaged in personal and isolated construction of meaning, as if reading, for example, is just a process of attending to the surface of language. It privileges the mind and the individual over the sociocultural context of the child's learning.

\section{Haemi:}

Some current assessment practices in Ontario attempt to create spaces for multiliteracies or account for sociocultural influences (see The Achievement Chart for Language - Grades $1-8$ at http://www.edu.gov.on.ca/eng/document/policy/achievement/ charts1to12.pdf). This rubric considers the application of the reading and writing modes across contexts and alludes to other modalities (e.g., oral, visual, written, and media forms).

\section{Dorina:}

Literacy encompasses so many different modalities (e.g., aural, gestural, visual, linguistic, and spatial) (Kress, 2009) and we don't want to compartmentalize them - in combinations, they enhance each other. We don't want to conceptualize literacy as "monomodal" (Vincent, 2006). We have to problematize the term "literacy" and consider the rich multimodal interplay of meanings.

Scene 2, still morning, while the friends sip tea: Multiliteracies

\section{Ferintosh:}

I like to define literacies as any representation of ideas using symbols. Like Vygotsky (1978), I believe that young children's gestures are symbolic representations of meaning that are precursors to writing. For young children, gestures are "first-order symbols", as they represent directly and concretely the objects or actions to which children are referring when they want to communicate with others. Over time, children learn that written symbols designate ideas represented in speech. As such, written language is "second-order symbolism" (Vygotsky, 1978, p. 115). For me, drawings and 
other visual representations, as well as written language, and dramatic movement are second-order symbols that communicate meaning, and thus can be identified as literacies.

\section{Haemi:}

Children's gestures? Culturally shaped modes.

\section{Ferintosh:}

Any gestures that are purposeful and that are meant to express something, or to get someone to do something. I believe that reading and writing should be defined very, very broadly....

\section{Dorina:}

Can we say that writing is any kind of representation with symbols, and reading is any kind of making meaning, from any kind of symbol?

\section{Amherst:}

Kress (1997) theorizes reading in two principles: (1) reading is sign-making as the text offers the "substance or materiality" for the reader to construct a new sign; and (2) the boundaries of text making are determined by the reader (p. 46). The child's "experiences, knowledge and interest" (p. 47) shape these processes. Of course, these boundaries are socially shaped and can be reconsidered at any time. Writing is a multimodal construction of the resources at hand as they are reused to make new signs.

\section{Ferintosh:}

That's what I believe.

\section{Dorina:}

Then we'll be including videotaping with handheld devices like smart phones and small digital cameras, we'll be including reading billboards, creating multimedia presentations, and so on. Still, writing is the creation of symbols and reading is the interpretation of symbols.

\section{Amherst:}

Very much so. Embracing the potential of symbols and gestures, a constructivist approach, would involve considering those as the first steps of what can turn into writing. It's the same with children's drawings. We could look at the pictures that children draw and think, wow, they can write. Or you could think, wow, this is the beginning of a text that can be turned into writing. Children make meaning multimodally by drawing on the resources that are sociopolitically available to them.

\section{Ferintosh:}

Are we taking the gestures and drawings as preliminary steps toward writing, or can we treat them as legitimate ways of expressing, as literacies on their own right? Think about drama, or music. If we asked artists and those who think about performance, 
I think they would define what they do as literacies, keeping in mind that each mode has particular affordances and constraints (Kress, 1997).

\section{Dorina:}

Of course, when we think about really young babies and children, their performance is just moving their bodies to express something. Right? So if you think about professional performances, can it be the same thing? So then it doesn't have to be a preliminary step towards another literacy practice?

\section{Amherst:}

It's one literacy. Let's take into account that throughout human history, people have used their bodies and environments as resources to "interconnect" with each other (Finnegan, 2002). Digital technologies have raised our awareness of the multiple ways that people communicate.

I think that we do need to be careful in lumping all literacy practices together, though. Certainly, there are literacies that have more social relevance and power within particular contexts and interactions than others and we need to keep that at the forefront of this work, and consider the social purpose of these practices. So we've got all these literacies, and then you're suggesting that we have to define them more broadly and recognize them across contexts.

The problem is that defining them broadly takes them out of context and isolates them from power relations. And so, while I love these broad definitions of literacies, I'm still worried: Can we have the broad, with the particular, that is, the local, context-based practices? We need to consider what children do with their everyday literacies alongside the practices that are associated with languages of power (e.g., standard dialect of Canadian and American English) and school literacies.

\section{Scene 3, later that afternoon: Multiliteracies and Assessment}

\section{Ferintosh:}

Let's first talk about what we believe should be at the center of assessment associated with multiliteracies pedagogies.

\section{Amherst:}

I think that the reading process cannot be discretely isolated from other kinds of school learning and other language modes. It is also important that all students, regardless of their sociocultural and linguistic backgrounds, should be expected to actively engage in the four literacy practices identified by Luke and Freebody (1999). For example, code breaking, cognitive-psychologically-based practices, is not learned first, in isolation from the other literacy practices. Code breaking is learned as children engage with text participation, text use, and text analysis, as children make meaning and use texts. Code breaking includes alphabetic and letter-sound knowledge. While the teaching of phonics is an important part of literacy learning, it is problematic to begin there, decontextualized (Hornsby \& Wilson, 2010). 


\section{Dorina:}

Right. And think about the ongoing phonics discussion: "Phonics" assigns a fixed sound value to each letter, a difficult matter in the English language. In English, there are more speech sounds than there are letters (i.e., 26 letters to 42 to 44 sounds in spoken English) because we have different letters and letter combinations to represent the same sound. In addition, many languages have influenced the development of English through cultural contact and conquest, with spelling patterns reflecting these other languages. Lastly, there are many varieties of spoken English, with different accents producing different pronunciations and speech sounds. We need to ask ourselves, "Whose phonics do we teach?" (Wilson, 2002).

\section{Ferintosh:}

And to add my two bits, text participation, psycholinguistic and sociocultural practices, take children inside the text. Text participants understand and construct meaningful written, visual, spoken texts from prior experiences with these texts and storylines. Children are invited to interact and to ask questions of the text. Text using, sociocultural practices, requires the reader not only to understand and participate but also to make use of the text by considering form, purpose/function, and audience. The text critic understands that texts are ideological: They represent particular worldviews and silences, and influence how people perceive themselves in the world. Text analysis, sociopolitical practices, requires that the reader step back from the text and examine the explicit and implicit social messages imbedded in its words and images.

\section{Haemi:}

This four-resources model doesn't represent a continuum or linear process, but a dynamic repertoire of practices. Children enact these practices depending on their prior literacy experiences (e.g., genre and cultural themes) and the social context of the literacy event. This resource model is not bound to a developmental or pedagogical schedule; it honors what children know, the cultural and linguistic resources children bring to school literacy events.

\section{Amherst:}

Children shouldn't have to wait until they become fluent in English before they become critically literate. ${ }^{\text {ii }}$ What I've learned from my work with children, teachers, preservice teachers, and graduate students is that critical literacy contributes to and deepens the process of learning English as an additional language because, as Barbara Comber (2001) reminds us, just like we should possess high expectations for all children to learn language, we also should embrace the fact that all children have the ability to understand the social consequences of language use in texts and micro-interactions. Students' sociocultural and linguistic experiences are valuable resources for learning multiliteracies.

\section{Dorina:}

Well said. An ability to understand written text critically should be a goal for all children. Critical literacies should be core expectations. Really, theories of multiliteracies and second language learning should inform and reflect each other. 
They're not two separate processes. But learning a second language at the same time that one is learning to read makes it very, very complex, because the sociocultural and sociopolitical experiences of the learner and the school learning environment play such important roles.

\section{Haemi:}

It sounds like we all agree that reading doesn't just happen in people's heads. Reading involves all the other language processes. It's a complex web of processes that happen within complex social relations. Reading is sociocultural and sociopolitical practices. Bloome and Dail (1997) invite us to consider that the reading event includes the following: "Who can do what, with what texts, how, in which situations, when, with whom, and with what social consequences" (p. 611).

\section{Ferintosh:}

How children are taught to read shapes how they interact with, use, and interpret texts. School literacy practices, the ones represented in the assessment tools, at any rate, tend to define comprehension at the text level: If children can "retell" what is in the text, they understand the text. But we align ourselves with a more complex view of comprehension; it's an intertextual process (Botelho \& Rudman, 2009). Because texts are cultural products, texts draw on other texts. When children read, they read a text against what they know about the world, their experience with similar texts, and other literary or nonliterary texts circulating in the reading text. The kind of reading they are expected to perform, the context, and the people involved in the reading event make a difference in understanding, as well. The intertextuality is socially created within the space in which the reading takes place, so it varies from reader to reader, and from context to context.

\section{Amherst:}

Rubrics for assessing reading, like those used to assess writing, standardize the reading process and mask the complexity of these social relationships, isolating the child reader from these social factors. The underlying assumptions imbedded in rubrics are that the literacy event is separate from the contexts and other practices, texts and literacies constructing the literacy moment. Rubrics discourage children to experiment, take risks, and collaborate in their reading, taking the focus away from the social processes involved in the meaning the child is making.

\section{Haemi:}

What kinds of reading are students expected to be able to do? Are English language learners expected to develop the same practices as fluent English speakers?

\section{Amherst:}

The Ontario Ministry of Education has designed "achievement charts" (see http://www.edu.gov.on.ca/eng/policyfunding/growsuccess.pdf) to assess student performance across the grades and disciplines, considering the following categories and skills: knowledge and understanding, thinking, communication, and application. 
Knowledge and understanding focuses on subject-specific content and sense making. Critical and creative thinking practices and communication through multiple forms are central to learning. Lastly, application attends to the use of knowledge and practices in multiple contexts. While the achievement charts recognize multimodal literacies, they lack criteria that foregrounds the complexities and processes of text production. Many teachers are inexperienced with multimodal text-making.

\section{Dorina:}

It's difficult to reflect multiliteracies in a rubric because it standardizes the reading and writing processes and isolates reading and writing from other language modes. What is the role of the child's first language in reading and writing? Does speaking, does drawing, for example, have places in this rubric? Are they present? If not, in what ways can drawing, drama, or multimedia production like digital storytelling, for example, provide a window into a child's literacy learning and understanding?

\section{Amherst:}

How do we reconstruct assessment tools to reflect multiliteracies? Is this possible?

\section{Final Act}

One week later, back in Dorina's office: The Shifts

\section{Haemi:}

Where have all our questions led us? What kind of insights can we learn from this questioning?

\section{Amherst:} considerations:

I think multiliteracies encourage us to take into account the following

First, context - assessment constructs school literacy practices and school literacy practices construct assessment. Assessment tools should acknowledge children's wide array of literacy practices across many contexts as well as seeking connections modes and media.

\section{Ferintosh:}

The most powerful assessment tools available are observation and conversation: Observing children in action and talking with children about their intentions and processes should be central to our work. Assessment tools should consider a diversity of literacies, languages, modalities, and texts as well as acknowledge children's flexible and collaborative practices associated with this work (Kalantzis, Cope, \& Harvey, 2003). Multiliteracies are an "intentional deployment of resources" (Kress, 2000, p. 340), a process of transforming available resources that represent the interests of the learner.

\section{Amherst:}

A critical dimension of that work is "dialogically observing and assessing" (Bomer \& Bomer, 2001) with children how the classroom community uses language, inviting the whole class to take ownership and responsibility of the learning and teaching 
processes. Children and teachers can digitally record discussions about their multiliteracies work (e.g., text circle conversations) and analyze their language use as well as literacy practices. One of the challenges is to identify language that can describe concepts, goals for performance, criteria for assessment in multimodal learning, and a metalanguage for describing multimodal meaning-making (Wyatt-Smith \& Kimber, 2009). Metalanguage will make these processes public.

\section{Ferintosh:}

Yes. In fact, Johnston and Costello (2005) remind us that assessment practices shape how we talk about children. How we use language to describe children's literacy learning can represent the challenges residing with the child, as if they are innate qualities, distracting us from "the struggle" that might have been constructed by our teaching practices in the first place. For example, when we say "the children are struggling with such and such..." the verb "struggle" signifies the children's efforts, but if we use the word "struggle" as an adjective to describe children as literacy learners, that is, struggling readers or writers, we leave the problems with the children, as if literacy challenges are inherent to them. Sometimes, inexperience with particular school literacy practices can play a part in these "struggles."

\section{Dorina:}

Much of school assessment practices depend on "notions of incompetence or failure" (Sefton-Green, 2009, p. 196). Bearne (2009) offers some possibilities for terms to describe facility with multimodal text making: "emergent stages; increased facility; more experienced and often independent; and assured, experienced, and independent multimodal text-maker" (p. 23). These ways of talking about children's learning document children's access to, exposure, experience, and apprenticeship with multimodal text making (Botelho \& Rudman, 2009). Assessment criteria are connected to the resources and resourcefulness of the child designers.

\section{Amherst:}

Wyatt-Smith and Kimber (2009) have identified six concepts that are connected to multimodality and useful to assessing children's literacies. They maintain that each concept highlights elements related to multimodal text making. The concept of design names the dynamism of multimodal text making through the linguistic, visual, audio, gestural, spatial, and multimodal design elements. The concept of visualization of literacy defines a grammar of visual design such as language, image, color, typeface, movement, and texture. The third concept, modes and modal affordance, helps to determine how different modes (words, images, sounds, colors, gestures, and movement) shape multimodal texts and how modes are enlisted and combined. The concept of transmodal operation shows how a student designer moves between and across various modes to represent meaning. The fifth concept is cohesion calls attention to how visual, verbal, and aural elements utilized and mixed are harmonious. Staged multimodality, the sixth concept, foregrounds the students' deliberate design in the construction of the text. 


\section{Ferintosh:}

These six concepts or criteria offer language for metamodality to attend to the process, product, and reflection of multimodal meaning-making. Stein (2008) maintains that multimodalities afford children with opportunities to represent from multiple perspectives, foregrounding how different modes interact in dialogue or conflict with each other. These multiple resources work across knowledge boundaries and produce multiple narratives, engaging multiple audiences. Multimodal work contributes to children's awareness of the social construction of each text. Text production contributes to critical literacies.

\section{Dorina:}

All children should have access to critical literacies or critical media literacy practices, because, as we've learned, these critical practices deepen the other literacy practices. Besides text critiquing, assessment should include children's text using, text participating, and code breaking practices (Luke \& Freebody, 1999). ${ }^{\text {iii }}$

\section{Haemi:}

For example, writers will feel the need to modify their writing processes to meet the sociopolitical demands of changing contexts. It's not enough to examine students' writing processes; these writing processes must be considered in terms of the sociopolitical purposes of the students' writing and the influences of the context on the intentions, style, form, content, and processes the students demonstrate.

\section{Amherst:}

Writing assessment would include how peers respond to the student's writing, how the student expects peers to respond, and what they do to ensure these responses. This could extend to looking at a diversity of examples in efforts to broaden students' perspectives on acceptable social meanings that can be communicated in their writing. In student-teacher conferences, teachers could ask students about their processes in terms of the demands of the writing context, in addition to observing what students did to plan, write, revise, and edit. They also could take notice of the role of collaboration (Daniels \& Harvey, 2009) and speaking (Elbow, 2012) for writing and revising, for example. The assessment of these writing processes unsettles the construct of voice in writing from who wrote the text to one that foregrounds the young writers' decision-making and deployment of discourses in their writing (Kamler, 2001).

\section{Ferintosh:}

And let's not forget that we shouldn't underestimate the power of project, performance, group, and portfolio assessments (Kalantzis, Cope, \& Harvey, 2003). Project assessment considers children's in-depth plans and tasks as well as the processes of data collecting, interpretation, and presentation, practices that require flexibility and use of multiple knowledges. Performance assessment takes into account children's planning, doing, and completion of particular tasks, all drawing on a repertoire of practices including organization and problem-solving. Group assessment takes notice of 
individual and collaborative participation in group work. Portfolio assessment showcases children's multiliteracies. Process portfolios feature the multiple stages of text production, and product portfolios exhibit the child-selected final drafts of projects.

\section{Haemi:}

So, portfolios could be online repositories in students' weblogs, for example, that would invite children to showcase their experiences with all the literacies - speaking, listening, writing, reading, representing, and viewing (Pahl \& Rowsell, 2005/2012). Digital literacies offer many options for documenting multiple modes in action.

\section{Dorina:}

Yes. Keeping in mind that multiliteracies call upon different combinations of these language modes, students could highlight their writing and representing through uploading photographs and by including links in their portfolio blogs to websites they have created. They could demonstrate their writing and speaking through radio plays that they have recorded on podcasts.

\section{Amherst:}

Exactly. Children can gather artifacts that represent multiple literacy practices, which are connected to their multiple identities. Portfolios can document children's processes over time, telling the "whole story" about their literacy learning. Interviews, self-assessments, surveys, and questionnaires can provide insights into children's design decisions (Stornaiuolo, Hull, \& Nelson, 2009).

$* * * * * * * * * * * * * * * * * * * *$

\section{Epilogue}

Researchers in education and social sciences have begun to explore alternative forms of representing scholarly work by using both literary (e.g., poetry, autobiography, theater plays, and fiction) and multimodal forms, such as photos, videos, music, textile, and dance performance. In this article, we used a dialogic text deliberately to experience multiliteracies and to problematize the assessment of school literacies. Like multiliteracies learning, we produced knowledge through dialogue and representation, while examining how knowledge and power work together, as we analyzed the discourses in our collective text. We drew on the discourses from our respective fields of expertise and drew on multiple modes (i.e., speaking, listening, writing, reading, representing, and viewing) for generating and interpreting our data. In the end, we produced a hybrid text that has engaged viewers and readers in multiple ways, while making our learning available to the reader. This representation allowed us to focus on our discursive practices and text production.

Multiliteracies pedagogies seek to recognize and connect the language modes of speaking, writing, representing, listening, reading, and viewing. Teachers invite children to use their home/community languages and literacies as resources for classroom learning, positioning children as creators and researchers of language, helping them to become more aware of the role that language plays in social processes, and guiding all children to 
access languages of power and school literacies. We consider reading and writing as sociopolitical practices that can be used as tools for reconstructing identities, worldviews, and society. We maintain that commonly used literacy assessment tools seldom acknowledge multiliteracies, and re/present the ambiguity in these assessment practices.

We argue that this ambiguity is not necessarily problematic. Rather, it encourages us to engage multiple perspectives and foreground the complexities and nuances of this ambivalence in order to enhance mutual understandings of lingering questions such as: How are multiliteracies perceived, experienced, and appreciated by various educational stakeholders (e.g., students, teachers, parents, and the public)? What value commitments and conditions are enacted in practicing multiliteracies and assessing these practices? What are the essential characteristics of multiliteracies assessments? What constitutes "good" assessment of multiliteracies? What kind of literacy practices do our assessment tools privilege? Which literacy practices are obscured by our teaching and research? In what ways can we reconstruct the available assessment tools? What other tools do we need to document the complex processes of multiple language modes?

As researchers and practitioners, we must examine how we define literacy and assessment because our definitions will influence how we teach, how we perceive children's learning in the classroom, and what we deem worthy of assessment. Literacy and assessment practices are socially shaped. School assessment practices require rethinking from individual-, reading/writing-, and print-based practices to ones that acknowledge the sociocultural and sociopolitical dimensions of multiliteracies, that is, recognizing children's multiple linguistic experiences such as their language resources and production of digital, multimodal, and multi-genre texts. This shift acknowledges children's flexibility with literacies (i.e., drawing on multiple language modes) and their collaborative text production practices, creates additional "opportunities for learning" (Gee, 2003), and focuses on children's meaning making - text making - and foregrounds the children's intention. Respect for children's cultural and linguistic knowledge fosters local democracies (Botelho, 2008).

While deconstructing and reconstructing our assessment tools are central to assessing multiliteracies, two other issues need consideration: familiarity with multimodalities and school structures. Teachers need space to take stock of the multimodalities they know, explore the ones their students' know, as well as expand their repertoires of practice. These explorations can take place through observation of and conversation with children, critical collaborative inquiry, in-service teacher education, and graduate study. For example, one author has designed an online course that invites course participants to explore multimodalities within and beyond digital technologies so teachers can learn about these processes and practices. The annual practice of shuffling students and teachers requires attention too. If teachers were expected to stay with students beyond one-year periods, they would come to know children's cultural and linguistic resources more intimately and be ready to build on them at the beginning of each school year. Looping with children two to four years would enhance assessment practices as teachers accumulate knowledge about each child's cultural and linguistic practices. A great opportunity is missed with the current structure of public schools.

Assessment shapes classroom learning and teacher-student interactions. Teachers, administrators, and families need to take stock of these school practices. When 
assessment tools are reconstructed and/or replaced, these shifts in practice change what is counted as knowledge in schools. As we consider assessment practices, we must ask ourselves which tools offer insight into assessment for learning (i.e., diagnostic and formative practices as interviews and observation), assessment as learning (i.e., formative practices as self- and peer-feedback), and assessment of learning (i.e., summative practices as portfolio review) (Earl, 2013). One assessment tool offers one snapshot of learning. Multiple assessment practices offer many snapshots of classroom work, providing a panoramic view of children's engagement.

We invite you, the reader, to emulate our critical collaborative inquiry practices as a way to take stock of your collective understandings and questions, as well as to locate spaces for further critical inquiry. We recommend reviewing the research and professional literatures and juxtaposing these works with what you already know. Let your experience contribute and "talk back" to our dialogue.

\section{References}

Abma, T.A. (2002). Emerging narrative forms of knowledge representation in the health sciences: Two texts in a postmodern context. Qualitative Health Research, 12(1), 5-27.

Botelho, M. J. (2007). Naming practices: Defining critical multicultural literacies. Orbit, $36(3), 27-30$.

Botelho, M. J. (2008). Re-reading the Text. In S. Nieto (Ed.), Dear Paulo: Letter from those who dare teach (pp. 150-153). Boulder, CO: Paradigm Publishers.

Botelho, M. J., \& Rudman, M. K. (2009). Critical multicultural analysis of children's literature: Mirrors, windows, and doors. New York, NY: Routledge.

Botelho, M. J., Cohen, S., Leoni, L., Chow, P., \& Sastri, P. (2010). Respecting children's cultural and linguistic knowledge: The pedagogical possibilities and challenges of multiliteracies in schools. In M. L. Dantas \& P. Manyak (Eds.), Home-school connections in a multicultural society: Learning from and with culturally and linguistically diverse families. New York, NY: Routledge.

Bakhtin, M. M. (1986). The problem of speech genres. In C. Emerson \& M. Holquist, Speech genres and other late essays (V. W. McGee, Trans., pp. 60-102). Austin, TX: University of Texas Press.

Bearne, E. (2009). Assessing multimodal texts. In A. Burke \& R. F. Hammett (Eds.), Assessing new literacies: Perspectives from the classroom (pp. 15-33). New York, NY: Peter Lang.

Bloome, D., \& Dail, A. R. K. (1997). Toward (re)defining miscue analysis: Reading as a social and cultural process. Language Arts, 74(8), 610-17.

Bomer, R., \& Bomer, K. (2001). For a better world: Reading and writing for social action. Portsmouth, NH: Heinemann.

Brown, I., Lockyer, L., \& Caputi, P. (2010). Multiliteracies and assessment practice. In D. Cole \& D. L. Pullen (Eds.), Multiliteracies in motion: Current theory and practice_(pp. 191-206). New York, NY: Routledge.

Bryant, P. (1994). Reading research update. Child Education, 13-19. 
Burke, A., \& Hammett, R. F. (2009). Assessing new literacies: Perspectives from the classroom. New York, NY: Peter Lang.

Chall, J. (1983). Stages of reading development. New York: McGraw-Hill.

Cole, D., \& Pullen, D. L. (Eds.). (2010). Multiliteracies in motion: Current theory and practice. New York, NY: Routledge.

Comber, B. (2001). Critical literacy: Power and pleasure in the early years. Australian Journal of Language and Literacy, 24(3): 168-183.

Comber, B., \& Simpson, A. (2001). Negotiating critical literacies in classrooms. Mahwah, NJ: L. Erlbaum Associates.

Cope, B., \& Kalantzis, M. (Eds.). (2000). Multiliteracies: Literacy learning and the design of social futures. New York, NY: Routledge.

Cope, B., \& Kalantzis, M. (2013). "Multiliteracies": New Literacies, New Learning. In M. R. Hawkins (Ed.), Framing languages and literacies: Socially situated views and perspectives (pp. 105-135). New York, NY: Routledge.

Cummins, J. (2004). Multiliteracies pedagogy and the role of identity texts. In K. Leithwood, P. McAdie, N. Bascia, \& A. Rodigue (Eds.). Teaching for deep understanding: Towards the Ontario curriculum that we need (pp. 68-74). Toronto, ON: Ontario Institute for Studies in Education of the University of Toronto and the Elementary Federation of Teachers of Ontario.

Cummins, J., Brown, K., \& Sayers, D. (2006). Literacy, technology, and diversity: Teaching for success in changing times. Boston, MA: Allyn \& Bacon.

Daniels, H., \& Harvey, S. (2009). Comprehension and collaboration: Inquiry circles in action. Portsmouth, NH: Heinemann.

Davies, B. (2000). A body of writing: 1990-1999. Walnut Creek, CA: Altamira Press.

Dyson, A. (2003). The brothers and sisters learn to write: Popular literacies in childhood and school cultures. New York, NY: Teachers College Press.

Earl, L. (2013). Assessment as learning: Using classroom assessment to maximize student learning. (Second Edition.) Thousand Oaks, CA: Corwin.

Elbow, P. (2012). Vulgar eloquence: What speech can bring to writing. New York, NY: Oxford University Press.

Finnegan, R. (2002). Communicating: The multiple modes of human interconnection. New York, NY: Routledge.

Gee, J. P. (2003). Opportunity to learn: A language-based perspective on assessment. Assessment in Education, 10(1): 27-46.

Goldstein, T. (2008). Multiple commitments and ethical dilemmas in performed ethnography. Educational Insights, 12(2). Available from http://www.ccfi.educ.ubc.ca/publication/insights/v12n02/articles/goldstein/index. html.

Goodman, K. S. (1986). What's whole in whole language? Portsmouth, NH: Heinemann.

Hall, K. (2003). Listening to Stephen read: Multiple perspectives on literacy. Philadelphia, PA: Open University Press.

Holdaway, D. (1979). The foundations of literacy. New York: Ashton Scholastic.

Hornsby, D. \& Wilson, L. (2010). Teaching phonics in context. Urbana, IL: National Council of Teachers of English. 
Horton-Salway, M. (2001). The construction of M.E.: The discursive action model. In M. Wetherell, S. Taylor, \& S. Yates (Eds.), Discourse as data: A guide for analysis, (pp. 147-188). London, UK: Sage Publications Ltd.

Janks, H. (2010). Literacy and power. New York, NY: Routledge.

Jewitt, C. (2003). Re-thinking assessment: multimodality, literacy and computermediated learning. Assessment in Education, 10(1): 83-102.

Johnson, D. \& Kress, G. (2003). Globalisation, literacy and society: Redesigning pedagogy and assessment. Assessment in Education, 10(1): 5-14.

Johnston, P. (2000). Running records: A self-tutoring guide. York, ME: Stenhouse Publishers.

Johnston, P., \& Costello, P. (2005). Principles for literacy assessment. Reading Research Quarterly, 40(2): 256-267.

Johnston, P. \& Rogers, R. (2001). Early literacy assessment. In S. B. Neuman \& D. K. Dickenson (Eds.), Handbook for early literacy research (pp. 377-389). New York, NY: Guilford.

Jones, S., Clarke, L., \& Enrique, G. (2010). The reading turn-around: A five part framework for differentiated instruction. New York, NY: Teachers College Press.

Kalantzis, M., Cope, B. \& Harvey, A. (2003). Assessing multiliteracies and the new basics. Assessment in Education, 10(1): 15-26.

Kamler, B. (2001). Relocating the personal: a critical writing pedagogy. Albany, NY: State University of New York Press.

Kress, G. (1997). Before writing: Rethinking the paths to literacy. New York, NY: Routledge.

Kress, G. (2000). Multimodality: Challenges to thinking about language. TESOL Quarterly, 34(2), 337-340.

Kress, G. (2009). Multimodality: A social semiotic approach to contemporary communication. New York, NY: Routledge.

Luke, A., \& Freebody, P. (1999). A map of possible practices: Further notes on the four resources model. Practically Primary, 4(2): 5-8.

Moss, P., Pullin, D., Gee, J., \& Haertel, E. H. (2005). The idea of testing: Psychometric and sociocultural perspectives. Measurement, 3(2), 63-83.

New London Group. (1996). A pedagogy of multiliteracies: Designing social futures, Harvard Educational Review, 66, 60-92.

Pahl, K., \& Rowsell, J. (2005/2012). Literacy and education: Understanding the new literacy studies in the classroom. Thousand Oaks, CA: Sage.

Peterson, S. S., Botelho, M. J., Jang, E., \& Kerekes, J. (2007). Writing assessment: What would multiliteracies teachers do? Literacy Learning in the Middle Years, 15(1), 29-35.

Pirbhai-Illich, F. (2010). Aboriginal students' engagement and struggles with critical multi-literacies. Journal of Adolescent and Adult Literacy, 54(4), 257-266.

Pirbhai-Illich, F., Turner, N., \& Austin, T. (2009). Using digital technologies to address Aboriginal adolescents' education: An alternative school intervention. Journal of Multicultural Education and Technology, 3(2), 144-162.

Rowsell, J. (2013). Working with multimodality: Rethinking literacy in a digital age. New York, NY: Routledge. 
Sefton-Green, J. (2009). Epilogue. In A. Burke \& R. F. Hammett (Eds.), Assessing new literacies: Perspectives from the classroom (pp. 193-197). New York, NY: Peter Lang.

Stein, P. (2008). Multimodal pedagogies in diverse classrooms: Representation, rights and resources. New York, NY: Routledge.

Stornaiuolo, A., Hull, G., \& Nelson, M. E. (2009). Mobile texts and migrant audiences: Rethinking literacy and assessment in a New Media Age. Language Arts, 86(5), 382-392.

Street, B. V. (Ed.). (1993). Introduction. Cross-cultural approaches to literacy (pp. 1-21). Cambridge, UK: Cambridge University Press.

Street, B. (2005). Introduction: New Literacy Studies and literacies across educational contexts. In B. Street (Ed.), Literacies across educational contexts: Mediating learning and teaching. Philadelphia, PA: Caslon Publishing.

Vincent, J. (2006). Children writing: Multimodality and assessment in the writing classroom. Literacy, 40(1): 51-57.

Vygotsky, L. S. (1978). Mind in society. Cambridge, MA: Harvard University Press.

Wells, G. (2001). The case for dialogic inquiry. In Action, talk, and text: Learning and teaching through inquiry. New York, NY: Teachers College Press.

Wells, G. (2007). Semiotic mediation, dialogue and the construction of knowledge. Human Development, 50(5): 244-274.

Wilson, L. (2002). Reading to live. Portsmouth, NH: Heinemann.

Wyatt-Smith, C., \& Kimber, K. (2009). Working multimodally: Challenges for assessment. English Teaching: Practice and Critique, 8(3), 70-90.

\section{Author Biographies}

Dr. Maria José Botelho is Assistant Professor of Literacy Education in the Language, Literacy, and Culture Concentration of the College of Education at the University of Massachusetts Amherst. She teaches graduate courses in children's literature, writing, critical literacies, ethnographic methodology, critical multiliteracies for preservice elementary teachers, and literacy assessment. Her research centers on re-imagining school literacies through critical literacies, multiliteracies, and Waldorf language arts pedagogies; critical multicultural analysis of children's literature; and critical collaborative inquiry as professional learning.

Dr. Julie Kerekes is an Associate Professor in Language and Literacies Education at the Ontario Institute for Studies in Education, University of Toronto. Her research and teaching focus on language and power in conversational and institutional settings, particularly workplace ESL, as well as on the professional development of second language teachers.

Dr. Eunice Eunhee Jang is an Associate Professor at the Department of Applied Psychology and Human Development in Ontario Institute for Studies in Education of the University of Toronto. Her research seeks to advance educational assessment practices by promoting students' self-regulated learning and informing instructional planning. 
Dr. Shelley Stagg Peterson is a Professor in the Department of Curriculum, Teaching and Learning at OISE/University of Toronto where she teaches initial teacher education and graduate courses in literacy and conducts research on writing assessment and instruction, oral language development, and approaches for supporting teachers' professional learning in northern communities.

${ }^{i}$ Pahl and Rowsell's Literacy and Education: Understanding the New Literacy Studies (Heinemann, 2005/2012), Cummins, Brown, and Sayers' Literacy, Technology, and Diversity: Teaching for Success in Changing Times (Allyn \& Bacon, 2006) and Cole and Pullen's Multiliteracies in Motion: Current Theory and Practice (Routledge, 2010) offer glimpses of these classroom practices.

${ }^{i i}$ See The Reading Turn-Around: Five Part Framework for Differentiated Instruction by Stephanie Jones and colleagues (Teachers College Press, 2010) and Reading to Live: How to Teach Reading for Today's World (Heinemann, 2002) and Writing to Live: How to Teach Writing for Today's World (Heinemann, 2006), both by Lorraine Wilson, to consider the four resource model enacted in the classroom. Jones and colleagues propose a fifth practice that is based on the literacy user's identity. We prefer to use subject position, a construct that turns teachers' gaze to how their lessons and practices shape students' possibilities for being and participating in their classrooms and beyond. Subject positions signify the complexities and fluidity of these micro-moments.

iii Consider Practicing Critical Literacy Work with English Language Learners: An Integrative Approach by Man Chu Lau (2010), an unpublished dissertation from OISE/University of Toronto, which examines English language learners and critical literacy practices in grades 7 and 8; Gebhard, Harman, and Seger's (2007) "Reclaiming Recess: Learning the Language of Persuasion," which documents a group of English language learners' experiences with using academic language to challenge school recess policies; and Pirbhai-Illich's (2010/2011) "Aboriginal Students' Engagement and Struggles with Critical Multi-literacies," and Pirbhai-Illich, Turner, and Austin's (2009) "Using Digital Technologies to Address Aboriginal Adolescents' Education: An Alternative School Intervention," which show how digital literacies offer opportunities for learning academic and critical literacies. 